\title{
Saudi EFL Learners' FLA: Levels, Causes, Gender, and Impact on Academic Performance
}

\author{
Rahaf A. Alsalooli \\ Saudi Commission for Health Specialties (SCFHS), Riyadh, Saudi Arabia
}

\author{
Mazeegha A. Al-Tale' \\ English Department, Faculty of Languages and Translation, King Khalid University, Abha, Saudi Arabia
}

\begin{abstract}
As a common psycholinguistic barrier that hinders EFL learning, Foreign Language Anxiety (FLA) has become an important study area in EFL learning and teaching. This study investigated the level and causes of FLA among 69 first-year EFL learners at Bisha University in Saudi Arabia. The influence of gender on the level of FLA was also examined. Moreover, the study examined the impact of FLA on the participants' language achievement. The researchers utilized a modified version of the Foreign Language Classroom Anxiety Scale (FLCAS). The Statistical Package for the Social Sciences (SPSS) and Microsoft Excel were used to analyse the data. The results showed that most learners typically had a moderate level of FLA caused by communication apprehension and fears related to negative feedback and language tests. The results also revealed that gender does not affect the level of FLA. In addition, the results indicated that high levels of FLA among learners had a significant impact on their performance. Based on these findings, this study provided recommendations for teachers to mitigate the causes of FLA.
\end{abstract}

Index Terms - Saudi EFL learners, communication apprehension, fear of negative feedback, fear of language tests

\section{INTRODUCTION}

It is well-known that English serves as the lingua franca of the global community. It is used extensively for communication in and between multilingual countries. As a result of globalisation, it is pivotal to effective participation in commerce, technology, and business today. Learning English has become essential in Saudi Arabia (SA) because immense transformations in the Saudi socioeconomic state of affairs have necessitated more emphasis on EFL education (Alotaibi, 2014). Faruk (2013) indicates that the Saudi Ministry of Education has asserted the importance of the English language as a vehicle to obtain knowledge in various fields. Over time, Saudi learners' needs regarding the acquisition of English have evolved from merely wanting to pass examinations to pursuing a genuine desire to acquire knowledge of the language, fuelled by the particular requirements of global communication and employment. These diverse everyday and workplace communication needs an acceptable level of English proficiency. However, researchers have reported that Saudi Learners of English as a Foreign Language (Saudi EFL learners) lack such levels of proficiency (Fareh, 2010; Khan, 2011; Al-Shammakhi \& Al-Humaidi, 2015).

It has been widely reported that Saudi EFL learners experience difficulties acquiring the English language. Alshanrani (2016) has demonstrated that Saudi EFL learners are still not proficient enough, despite the Saudi government undertaking EFL teaching and learning reforms by introducing the English language in primary schools in 2001. These poor results may be attributed to how learners attempt to acquire the language or how they feel while learning it; they may use methods of learning that are not suitable for them, which causes them to feel frustrated while learning it. In addition, many psychological factors like motivation and learning anxiety play a crucial role in EFL learners' achievements and performance over time (Abu-Ghararah, 1999; Mohammed, 2015; Alrabai, 2016). Anxiety particular to foreign language classrooms is called Foreign Language Anxiety (FLA), which MacIntyre (1999, p. 27) defines as "the worry and negative emotional reaction aroused when learning or using a second language." Several studies have examined learning anxiety in educational settings and found that EFL learners experience FLA, which negatively affects their performance (Melouah, 2013; Killu, Marc \& Crundwell, 2016; Melchor-Couto, 2017).

When it comes to learning a foreign language, anxiety may prevent language inputs from reaching the learner's mind and activating the language acquisition process (Krashen, 1982). According to Krashen's (1982) affective filter hypothesis on second language acquisition, high anxiety results in mental blocks that prevent inputs from reaching the student's mind and thus accelerating the language learning process. Researchers have also identified some reasons for FLA, including communication apprehension, the perceptions of teachers and colleagues, lack of self-esteem, low language proficiency, fear of negative feedback, and fear of conversing with native speakers. They have also confirmed that anxiety is one of the most common psycholinguistic barriers affecting language learning (Alrabai, 2016; Zheng \& Cheng, 2018; Manipuspika, 2018; Pérez, 2018; Al-Khotaba, Alkhataba, Abdul-Hamid, \& Bashir, 2019). The main 
sources of foreign language anxiety among Saudi EFL learners are fear of negative evaluation, communication apprehension, comprehension apprehension, and language tests (Al-Saraj, 2013).

\section{LITERATURE REVIEW}

A sizable body of literature has shed light on FLA in different parts of the world. Several researchers have considered FLA levels and sources and their impact on learning (Chan and Wu, 2004; Awan, Azher, Nadeem and Naz, 2010; Melouah, 2013; Zheng and Cheng, 2018; Hakim, 2019; Bensalem, 2020). For example, in Taiwan, Chan and Wu (2004) found that the five primary sources of FLA for EFL learners were low proficiency, fear of negative evaluation, competition anxiety, anxious personality, other students' feedback, and parental pressure. Meanwhile, Park and Lee's (2005) Korea-based study identified the relationship between college-level EFL learners' anxiety and oral performances, indicating that FLA had a significantly debilitating impact on their oral performance.

Awan et al. (2010) found that the three main causes of FLA in Pakistan were speaking in front of others, concerns about grammatical and pronunciation mistakes, and the inability to speak spontaneously. They also reported that FLA had an incapacitating impact on English as a second language (ESL) learners' achievement. Also, in Pakistan, Bhatti, Memon and Pathan (2016) investigated the factors that influenced FLA among 145 college ESL learners, finding that communication apprehension was the most prominent cause of anxiety among these intermediate-level students. This factor was followed by the fear of evaluation (either by teachers or by other students' feelings about their low proficiency), lack of confidence, nervousness, and lack of practice in various social contexts (Bhatti, Memon and Pathan, 2016). In Algeria, Melouah (2013) found that first-year license-master-doctorate (LMD) students had a debilitative FLA type in their speaking-skill classrooms, negatively affecting their speaking performance. Melouah's results also revealed six possible causes of FLA: fear of interactions; students' perceptions of the teacher and other students; lack of self-confidence; limited language proficiency; fear of negative correction and evaluation; fear of speaking with native speakers.

Also, Bensalem's (2017) Tunisian study concluded that EFL trilingual learners (male and female) experienced low and average levels of FLA, respectively, that could be attributed to the fear of failure in tests, English speaking apprehension, and classroom-related anxiety. Bensalem's study also showed that FLA had a debilitating impact on the learners' academic achievement, although it did not reveal significant differences in FLA between male and female English learners. In Kuwait, Salem and Abu Al Dyiar (2014) examined the differences between male and female EFL private primary school students in oral fluency and speaking anxiety, finding significant differences between male and female students' oral fluency, with males showing superior results. Moreover, Zheng and Cheng's (2018) investigation set in China found that FLA and cognitive tests were not significant predictors of university students' test performance. Although the participants did not perceive being anxious in either the classroom or testing settings at university, they did admit to feeling anxious when practicing English speaking skills in the classroom. Zheng and Cheng called for a better understanding of FLA to help teachers and students enhance their EFL teaching and learning practices.

In the Saudi context, Mohammed's (2015) Saudi-based research found that English language learners in Community College and the Faculty of Education at Shaqra University had a moderate anxiety level, negatively related to their academic performance. The study concluded that the fear of language tests was one of the causes of FLA among Saudi students and their social, environmental, cultural, and religious beliefs. Meanwhile, Alshahrani (2016) investigated gender as a variable in FLA in English language classes at King Khalid University (KKU), Saudi Arabia, concluding that there were no significant differences in the level of FLA between male and female EFL learners.

In another Saudi study, Hakim (2019) identified two anxiety-inducing causes of FLA among Saudi EFL learners inside and outside the classroom: the stress associated with achieving native-like proficiency and a stressful classroom environment caused by traditional English learning methods. Hakim found that other socio-cultural factors also contributed to FLA in Saudi Arabia, including beliefs, values, and feelings of insult. Al-Khotaba et al. (2019) reported that while Saudi EFL learners in their preparatory year at the Northern Border University with low-language speaking anxiety performed well in speaking tests, those with high language anxiety (LA) did poorly in speaking tests. The same study identified different types of LA, including personal, interpersonal, and classroom anxiety, while researchers recommended that learners' perceptions of FLA should be addressed. In Koka, Islam and Osman's (2019) study, EFL Saudi undergraduate students at KKU were found to experience FLA across all dimensions of English language learning, reading, writing, listening, and speaking. The researchers suggested specific management tools and techniques lessening anxiety among EFL learners and further research on FLA effects on EFL learners.

Bensalem (2020) found that gender played a role in the level of foreign language reading anxiety (FLRA) among EFL students studying general English courses at two Saudi universities, while female participants showed higher anxiety levels than their male counterparts. The study also revealed that three main factors caused FLRA: comprehension apprehension, dissatisfaction with reading ability, and lack of acquaintance with phonics rules. Bensalem's study showed that the participants' anxiety was ameliorated by experience abroad, knowledge of a third language, and positive views about their English reading proficiency. Gawi's (2020) Saudi study reported that male students enrolled in applied linguistics courses at Albaha University had a slightly higher level of communicative apprehension, moderate test anxiety, and low fear of negative evaluation. Meanwhile, Zemni and Alrefaee's (2020) study of Saudi EFL students concluded that the department (English or French) and years of study did not affect 
undergraduate female EFL students' reading anxiety. The same study also reported that text sources, such as unknown vocabulary and unfamiliar pronunciation, contributed more toward reading anxiety than private reading anxiety sources such as fear of committing mistakes and pronunciation difficulties. To reduce reading anxiety, Zemni and Alrefaee recommended that teachers enrich students' vocabulary and strive to improve their pronunciation.

\section{RATIONAL AND RESEARCH QUESTIONS}

Several researchers have considered FLA levels, sources, and impact on learning, but few have highlighted the role of gender (Salem \& Abu Al Dyiar, 2014; Alshahrani, 2016; Bensalem, 2020). While Salem \& Abu Al Dyiar (2014) and Bensalem's (2020) studies indicated that gender played a role in the levels of FLA; in contrast, Alshahrani (2016) and Bensalem (2017) found no significant differences in FLA levels between male and female foreign language learners. Since two of these previous studies were in the Saudi context yet arrived at different conclusions (Alshahrani, 2016; Bensalem, 2020), it is necessary to conduct more studies on FLA within the same context, including gender as a variable to examine whether Saudi male students differ from their female counterparts in terms of FLA. To add the literature on this issue, this paper will therefore investigate how first-year students at Bisha University in Saudi Arabia experience FLA; to what extent they experience its causes as proposed by Horwitz, Horwitz and Cope (1986); the role of gender in this context; how it impacts their academic performance. Hence, this study answers the following questions:

1. To what extent do Saudi EFL first-year college students at Bisha University experience FLA?

2. Does gender play a role in first-year English language learners' FLA levels at Bisha University?

3. To what level are the causes of FLA as proposed by Horwitz et al. (1986) experienced by Saudi EFL first-year college students at Bisha University?

4. What is the impact of FLA on the performance of Saudi EFL first-year college students at Bisha University?

\section{ReSEARCH Methodology}

\section{A. Participants}

The researchers utilized convenience sampling to select the participants. A total of 69 Saudi EFL learners (44 males and 25 females, aged 18 to 21 years) in the first year of college at Bisha University were randomly selected from four different classes within two courses: Basics of English Grammar 1 and Vocabulary Building 1. They all had completed nine years at school and one year of an intensive academic English language program, focusing on reading, writing, listening, and speaking skills. This sample was convenient and considered suitable for the study as the selected participants were in their first year in the English department, while intensive learning of EFL was new and challenging to them.

\section{B. Instruments}

The first instrument used to collect the data was a modified version of the Foreign Language Classroom Anxiety Scale (FLCAS) developed by Horwitz et al. (1986). Researchers have used this questionnaire in various contexts, and it has shown both high validity and reliability. It measures the levels of three main causes of FLA, communication apprehension, fear of negative evaluation, and test anxiety. This scale originally comprised 33 statements about the learners' feelings toward foreign language learning and their effects on their learning. The present study added six additional statements on speaking anxiety, and nine of the original 33 negatively worded statements were transformed and worded positively to reduce complexity in data analysis, specifically regarding the reverse scoring of these items. The phrase "foreign language" in the title of the questionnaire was also modified to "English language" since the present study's participants were English learners.

The modified questionnaire comprised two parts: the first sought information on the participants' backgrounds, including name, age, and gender, while the second contained 39 statements for a rating on a five-point Likert scale, fluctuating from $1=$ strongly disagree to 5=strongly agree. As seen in Table 1 below, the mean score on the modified FLCAS ranged from 39 to 195; low scores indicated low anxiety, and high scores indicated high anxiety.

TABLE 1.

FIVE-POINT LIKERT SCALE FOR THE MODIFIED FLCAS

\begin{tabular}{|l|l|l|l|}
\hline & Degree & Difference & Interval \\
\hline Strongly disagree & 1 & 0.79 & $1.0-1.79$ \\
\hline Disagree & 2 & 0.79 & $1.80-2.59$ \\
\hline Neutral & 3 & 0.79 & $2.60-3.39$ \\
\hline Agree & 4 & 0.79 & $3.40-4.19$ \\
\hline Strongly agree & 5 & 0.80 & $4.20-5.00$ \\
\hline
\end{tabular}

A specialist in statistics verified the reliability of the questionnaire, given to the sample of 69 respondents. Cronbach's alpha was 0.940 for the entire questionnaire (39 phrases), indicating a high reliability level.

The second data collection instrument was the end-of-preparatory-year students' GPAs, drawn from an achievement test designed by a group of experienced EFL professors at Bisha University. The participants took several tests that 
evaluated their English language proficiency in listening and reading comprehension, grammar, and vocabulary. These details are not included in the Appendix due to administrative constraints and the number of tests given.

The researchers employed Statistical Package for the Social Sciences (SPSS v.23) software to compute the responses obtained from the questionnaire and conduct a simple linear regression test to determine the effect of FLA on the participants' academic performance.

\section{Procedures}

\section{Data Collection}

Participants drawn from EFL learners in their first year at Bisha University in Saudi Arabia were given the modified FLCAS questionnaire and were informed about the nature of the study, its aims, and how to answer the survey items using the Likert scale. The English questionnaire was accompanied by an Arabic translation to reduce the impact of the participants' low English proficiency levels, as they were still at the second level of learning English. Cultural constraints in Saudi Arabia meant that the researcher could not distribute hard copies of the questionnaire to male participants, so copies were given to the head of the English Department, who assigned a teacher to collect the data. The same procedures were followed among the female participants, and all subjects were given 40 minutes to complete the questionnaire.

\section{Data Analysis}

To determine the levels and causes of FLA experienced by first-year EFL learners at Bisha University, SPSS v.23 was used to elicit the frequencies, percentages, means, standard deviations, and ranks. The researchers used the t-test to determine whether there were differences between males and females in FLA. Descriptive data were obtained from the questionnaire, such as frequencies, percentages, means, standard deviations, and ranks. The study used Microsoft Excel to represent the rank data graphically after separating the responses into items relating to the three main causes proposed by Horwitz, Horwitz and Cope (1986). Finally, the researchers used SPSS to perform a simple linear regression to examine the effect of FLA on the participants' academic performance.

\section{RESULTS}

\section{A. Anxiety Levels}

In response to the first research query, descriptive statistics were obtained to measure the participants' FLA levels. Their anxiety levels ranged between 62 and 191, with a mean value of 120.0870, indicating a moderate anxiety level (see Table 2, Figure 1).

TABLE 2.

DESCRIPTIVE STATISTICS FOR THE PARTICIPANTS’ ANXIETY LEVELS

\begin{tabular}{|l|l|l|l|l|l|l|}
\hline FLA & $\mathrm{N}$ & Minimum & & Maximum & Mean & Std. Deviation \\
\hline Total Score & 69 & 1.00 & & 3.00 & 2.3478 & .63769 \\
\hline Anxiety Level & 69 & 62.00 & & 191.00 & 120.0870 & 29.16875 \\
\hline
\end{tabular}

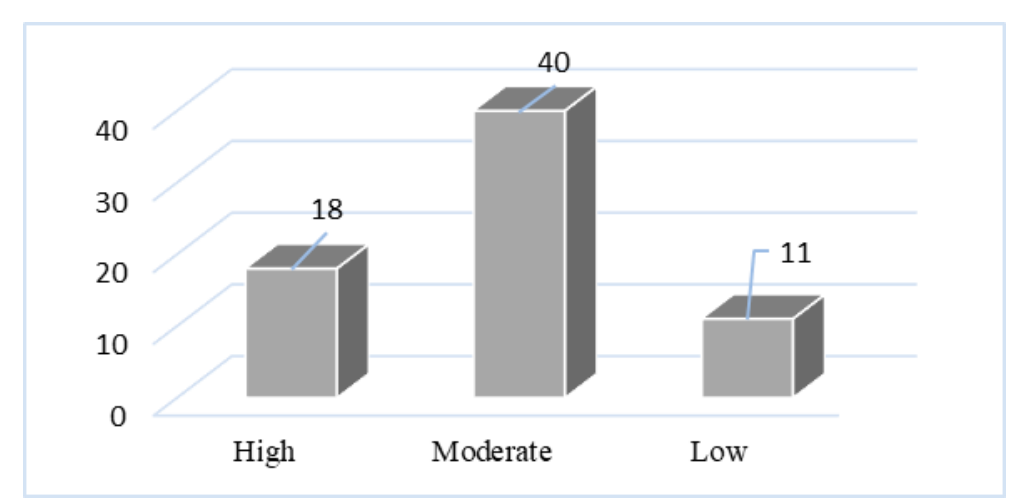

Figure 1. Participants' FLA levels

\section{B. Anxiety Levels and Gender}

A t-test was performed to compare the anxiety levels among males and females. Students who scored between 39 and 81 indicated a low level of anxiety in the English language classroom; those with scores between 81 and 125 displayed a medium level of anxiety; students who scored above 126 had high anxiety levels. The results are shown in Table 3. 
TABLE 3.

ANXIETY LEVELS AND GENDER

\begin{tabular}{|l|l|l|l|l|l|}
\hline & $\mathrm{N}$ & Mean & Std. Deviation & T & P-Value \\
\hline Male & 44 & 120.04 & 28.95 & 0.243 & .988 \\
\hline Female & 25 & 120.16 & 30.14 & & .988 \\
\hline
\end{tabular}

Table 3 shows that anxiety levels ranged between 62 and 177 for male students, with a mean value of 120.04, representing medium-level anxiety. For female students, the anxiety level ranged between 80 and 190, with a mean value of 120.16 , representing medium-level anxiety. Thus, the t-value was 0.243 with p-value $.988>.05$, which is not significant. Therefore, there were no gender-based differences in terms of FLA, as shown in Figure 2.

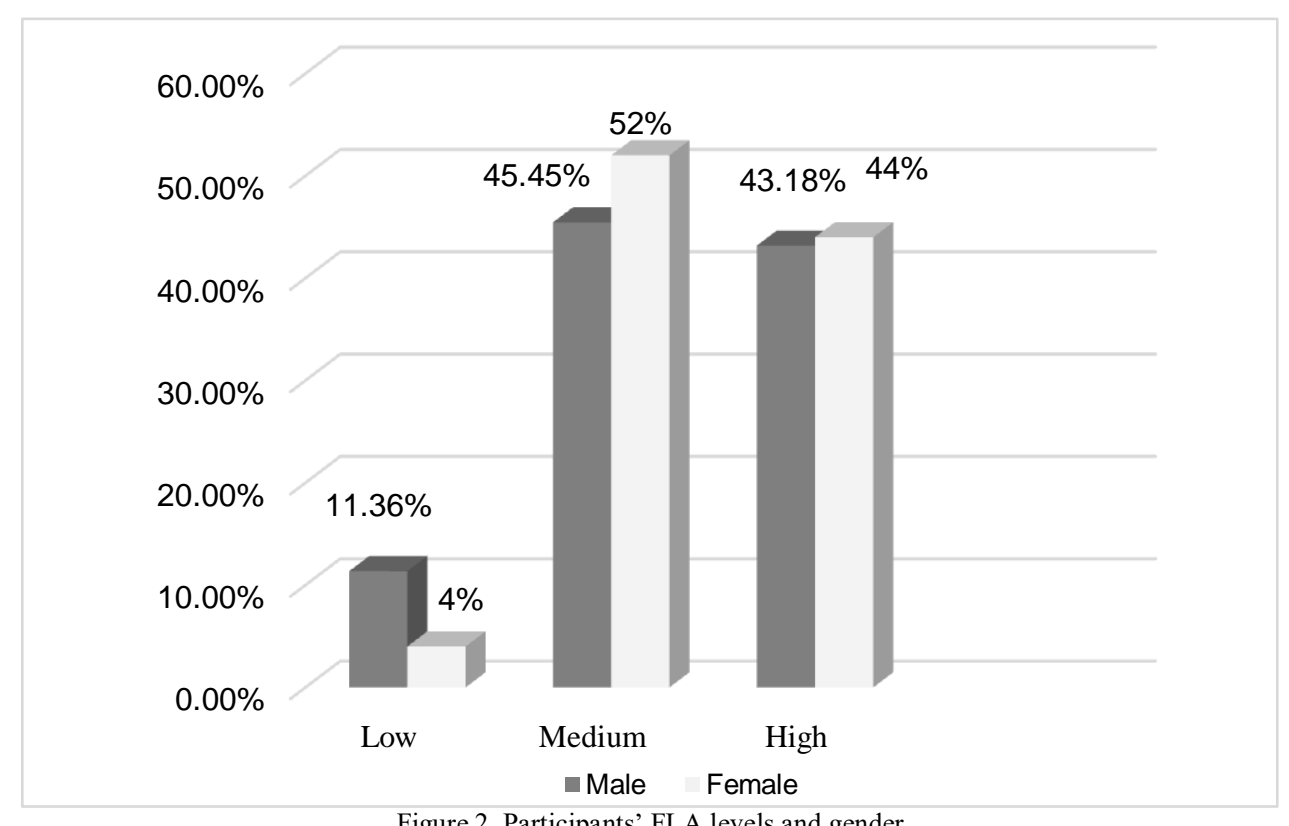

Figure 2. Participants' FLA levels and gender

\section{Causes of FLA}

To answer the third research query, the researcher obtained descriptive statistics for the participants' highest (6) items in the three main categories: communication apprehension, language tests, and fear of feedback from peers and teachers. The results are as follows:

\section{Communication Apprehension}

The analysis of the communication apprehension items revealed that the participants had a high level (3.40-4.19) of FLA speaking in English in front of other students. They also became upset when they could not understand the teachers' corrections (3.69). In addition, they tended to be nervous while speaking in English with native speakers (3.47). Moreover, they felt overwhelmed by the number of rules they had to learn to speak English (3.44); and that they got nervous when they did not understand every word their English teacher spoke (3.43). However, the participants were neutral about experiencing panic while speaking without preparation in English class (3.39). These results are presented in Table 4 and Figure 3 below:

TABLE 4.

DESCRIPTIVE STATISTICS FOR THE COMMUNICATION APPREHENSION CATEGORY

\begin{tabular}{|c|c|c|c|c|}
\hline Items & Mean & Std. Deviation & Rank & Degree \\
\hline 24- I feel very self-conscious about speaking English in front of other students. & 3.70 & 1.14 & 1 & Agree \\
\hline 15- I get upset when I do not understand what mistake the teacher is correcting. & 3.69 & 1.37 & 2 & Agree \\
\hline 14. I am nervous when I speak English with native speakers. & 3.47 & 1.36 & 3 & Agree \\
\hline 30- I feel overwhelmed by the number of rules I have to learn in order to speak English. & 3.44 & 1.32 & 4 & Agree \\
\hline 29- I get nervous when I do not understand every word the English teacher says. & 3.43 & 1.35 & 5 & Agree \\
\hline 9- I panic when I have to speak without preparing in English class. & 3.39 & 1.33 & 6 & Neutral \\
\hline
\end{tabular}


I panic when I have to speak without preparing in English class.

I feel overwhelmed by the number of rules I have to learn in order to speak English.

I get nervous when I do not understand every word the English teacher says.

I am nervous when I speak English with native speakers.

I get upset when I do not understand what mistake the teacher is correcting.

I feel very self-conscious about speaking English in front of other students.

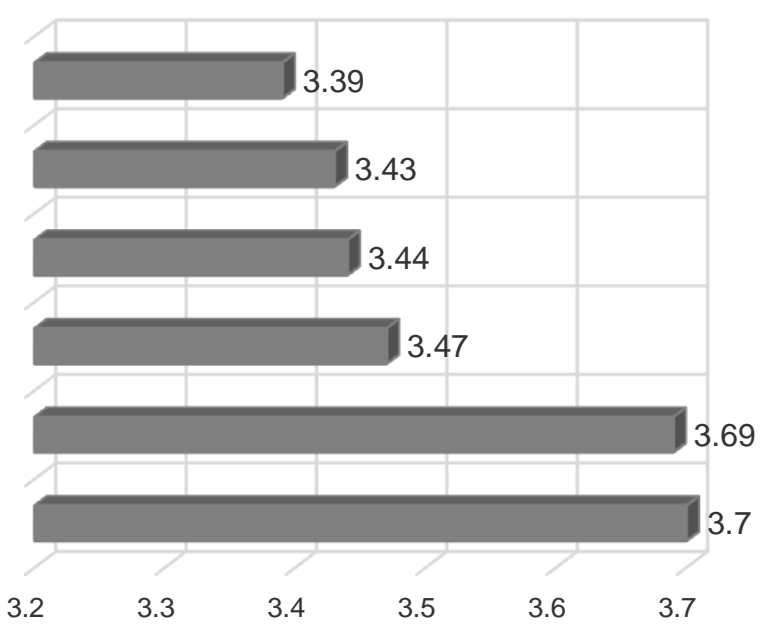

Figure 3. Participants' ranking for items related to communication apprehension

\section{Fear of Feedback}

The participants' responses suggested that they were also worried about making mistakes in their English class (4.22) and got nervous when the English teacher asked questions they had not prepared for in advance (3.43). However, they were neutral on four items related to fear of feedback:

1. The feeling that other students speak English better than they do (3.33).

2. Thinking that the other students in the class are better at languages than they are (3.14).

3. Feeling embarrassed to volunteer answers in their English class (2.6).

4. Fear that their English teacher is ready to correct every mistake they make (2.56).

TABLE 5 .

DescriPTIVE Statistics For FeAR OF FEedBack By PEERS AND TEACHERS

\begin{tabular}{|c|c|c|c|c|}
\hline Items & Mean & Std. Deviation & Rank & Degree \\
\hline 2- I worry about making mistakes in English class. & 4.22 & .97 & 1 & Strongly Agree \\
\hline $\begin{array}{l}\text { 33- I get nervous when the English teacher asks questions that I have } \\
\text { not prepared for in advance. }\end{array}$ & 3.43 & 1.44 & 2 & Agree \\
\hline 23- I always feel that the other students speak English better than I do. & 3.33 & 1.33 & 3 & Neutral \\
\hline $\begin{array}{l}\text { 7- I keep thinking that the other students are better at languages than I } \\
\text { am. }\end{array}$ & 3.14 & 1.26 & 4 & Neutral \\
\hline 13- It embarrasses me to volunteer answers in my English class. & 2.60 & 1.41 & 5 & Neutral \\
\hline $\begin{array}{l}\text { 19- I am afraid that my English teacher is ready to correct every } \\
\text { mistake I make. }\end{array}$ & 2.56 & 1.43 & 6 & Disagree \\
\hline
\end{tabular}




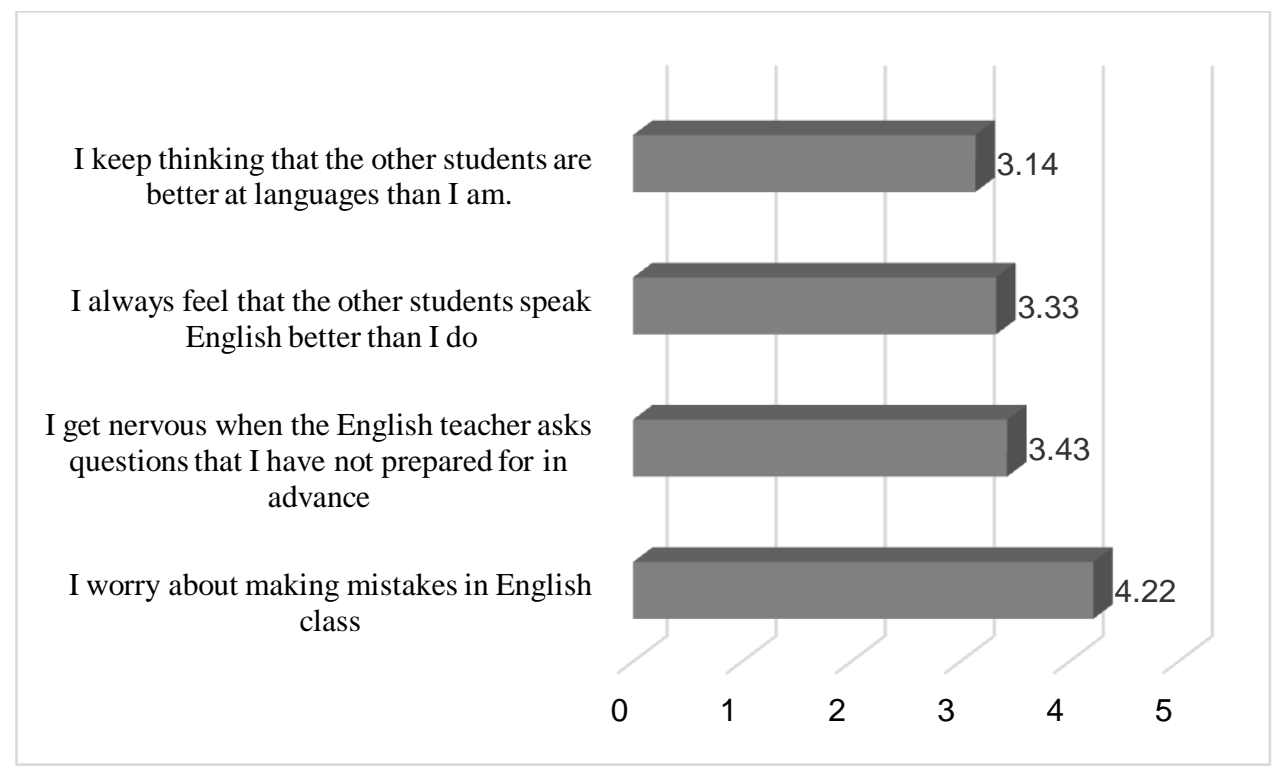

Figure 4. Participants' ranking for items related to fear of feedback

\section{Fear of Language Tests}

The participants reported that they were worried about the consequences of failing their English class (4.11). However, they also reported they understood why some people were upset over English classes (3.76). In addition, they felt their English lessons moved too quickly and were worried about being lagged (3.59). Moreover, they were usually not at ease during tests in their English class (3.47). Meanwhile, their responses to two questions were neutral. The first is thinking about aspects that have nothing to do with the course (2.89), and the second is related to the unwillingness to attend English class (2.86). The results are presented in Table 6 and Figure 5 below:

TABLE 6.

DESCRIPTIVE STATISTICS For FEAR OF LANGUAGE TESTS

\begin{tabular}{|c|c|c|c|c|}
\hline Items & Mean & Std. Deviation & Rank & Degree \\
\hline 10- I worry about the consequences of failing my English class. & 4.11 & 1.34 & 1 & Agree \\
\hline 11- I understand why some people get so upset over English classes. & 3.76 & 1.12 & 2 & Agree \\
\hline 25- English class moves so quickly I worry about being left behind. & 3.59 & 1.29 & 3 & Agree \\
\hline 8- I am usually not at ease during tests in my English class. & 3.47 & 1.50 & 4 & Agree \\
\hline $\begin{array}{l}\text { 6- During English class, I find myself thinking about things that have } \\
\text { nothing to do with the course. }\end{array}$ & 2.89 & 1.39 & 5 & Neutral \\
\hline 17- I often feel like avoiding English class. & 2.86 & 1.46 & 6 & Neutral \\
\hline
\end{tabular}

I often feel like not going to my English class.

During English class, I find myself thinking about things that have nothing to do with the course.

I am usually not at ease during tests in English class.

When English class moves so quickly, I worry about being left behind.

I understand why some people get so upset over English classes.

I worry about the consequences of failing in English.

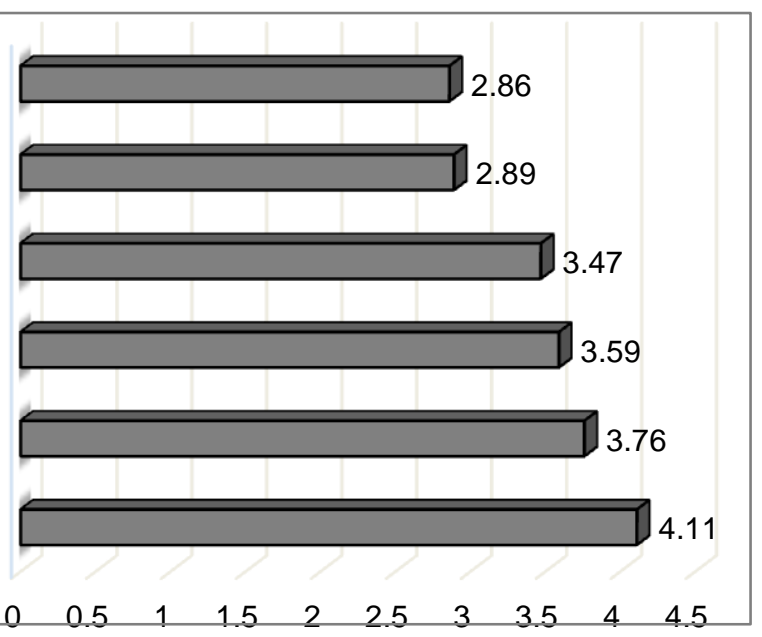

Figure 5. Participants' ranking for items related to fear of language tests 


\section{Effects of FLA on Academic Performance}

The results showed that FLA had an impact on learners' performance; the higher the FLA, the lower the learners' performance $(\mathrm{R}=.386, \mathrm{~F}=11.750$ and $\mathrm{P}$-value $=.001<.05)$. This result is shown in Table 7.

TABLE 7.

EFFECT OF FLA ON ACADEMIC PERFORMANCE

\begin{tabular}{|l|l|l|l|l|l|}
\hline \multirow{2}{*}{$\begin{array}{l}\text { Dependent } \\
\text { Variable: Grade }\end{array}$} & \multicolumn{2}{|l|}{ Unstandardized Coefficients } & $\begin{array}{l}\text { Standardized } \\
\text { Coefficients }\end{array}$ & \multirow{2}{*}{$\mathrm{T}$} & \multirow{2}{*}{ Sig. } \\
\cline { 2 - 5 } & $\mathrm{B}$ & Std. Error & Beta & & \\
\hline Constant & 95.199 & 5.470 & & 17.404 & .000 \\
\hline FLA & -.152 & .044 & -.386 & -3.428 & .001 \\
\hline
\end{tabular}

Table 7 presents the effects of FLA on the performance of EFL language learners (learners' grades), with the help of unstandardised beta coefficients with a negative value $(-.152)$ and significance (p-value $<0.05)$. The results show that one unit increase in the FLA level decreases 0.152 in learning performance. The regression equation is as follows:

Performance $($ Estimated $)=59.199-0.152($ FLA $)$

\section{CONCLUSIONS AND Discussions}

The study findings showed that most Saudi EFL college beginners experience a moderate level of FLA. This finding aligns with previous research findings (Mohammed, 2015; Alshahrani, 2016; Bhatti et al., 2016; Koka et al., 2019). They also revealed that gender did not affect FLA levels among EFL learners. This finding aligns with those of Alshahrani (2016) and Bensalem (2017). However, it differs from those of Salem and Abu Al Dyiar (2014) and Bensalem (2020), which confirmed the gender role in FLA.

Also, the findings confirmed the three main causes of FLA previously identified by Horwitz et al. (1986) and Park and Lee (2005), namely communication apprehension, fear of feedback from peers and teachers, and worries about English language tests. This result is similar to Gawi's (2020) finding reporting that Saudi students had different levels of communicative apprehension, fear of negative evaluation, and test-related anxiety. It also aligns with Bensalem's (2020) identification of comprehension apprehension as one of the main causes of FLA.

Moreover, this result also echoes Bhatti et al.'s (2016) conclusion that communication apprehension is the most prominent factor inducing anxiety among learners, followed by the fear of evaluation either by teachers or other students. In addition, it aligns with other scholars' conclusions that fear of language tests causes FLA for Saudi EFL learners (Mohammed,2015); that fear of being insulted could contribute to FLA (Hakim,2019); and that speaking in the presence of others is one of the main causes of FLA (Awan et al.,2010). Furthermore, it is consistent with Melouah's (2013) study, which identified the following as causes of FLA: fear of interaction, students' perceptions of the teacher and other students, lack of self-confidence, fear of negative correction and evaluation, and fear of speaking with native speakers. Finally, this finding aligns with Chan and Wu's conclusion (2004) that fear of negative evaluation and pressure stemming from other students' feedback and their parents are the main causes of FLA.

As for the impact of FLA on EFL learners' academic performance, the results showed that FLA significantly impacts EFL learners' performance, acting as a barrier that prevents students from attaining their fullest potential when learning a new language. This finding aligns with previous research that identified the debilitating effect of FLA (Park and Lee, 2005; Melouah, 2013). It also echoes Mohammed (2015), which found that FLA harms learners' motivation and achievement. Moreover, it aligns with Bensalem's (2017) assertion that there is an inverse relationship between a learner's FLA and their achievement in English language classes. Furthermore, this result resonates with Al-Khotaba et al. (2019), which found that high LA negatively affects students' speaking test achievement. However, it contradicts Zheng and Cheng (2018), which did not find FLA a significant predictor of test performance.

Therefore, despite the variations in the educational and demographic contexts among these studies, the results are unanimous. This cohesion of scholarly opinion supports the conclusion that a high FLA level is an important indicator of learners' slow language achievement, which naturally warrants a discussion on how much anxiety could be reduced. Discovering the causes of FLA as experienced by learners can help students, teachers, and curriculum designers to overcome the hurdles identified. Therefore, it is necessary to increase teachers' awareness of FLA in their classrooms and enlighten them about strategies that can lessen the consequences of FLA on their students. To mitigate communication apprehension among learners, teachers should keep the learning environment friendly and motivational. Meanwhile, teachers and syllabus designers should focus more on speaking rather than writing skills; while this does not imply that the focus should shift entirely to verbal skills, it calls for a better balance between the two, particularly given that much of the emphasis is currently on writing skills. A balanced approach can contribute toward minimizing communication apprehension anxiety.

To minimise the fear of negative feedback from peers, teachers should tell learners that mistakes are acceptable and stress that all learning processes involve errors. Moreover, instructors should explain that failure is a step toward success and explain that they have previously been in a similar position when they were learning. Finally, to reduce fear among students, teachers should also design more formative tests than summative ones. Hakim (2019) endorsed some 
of these recommendations and suggested that the general FLA level might be lowered by creating an effective and positive environment conducive to EFL teaching and learning.

\section{LIMITATIONS \& DiRECTIONS FOR FUTURE RESEARCH}

The present study has some limitations which can be compensated for in further research. The first limitation is that this study focuses on Saudi EFL beginner classes at a single Saudi university, so future studies could seek to validate or reject the findings of this study by investigating FLA levels and causes in different universities and with different levels of learners. Future researchers could also investigate whether the learners' English language proficiency affects the level of FLA they experience. The second limitation is that this study focuses only on the students' FLA without investigating their teachers' methods and awareness of FLA. To complement the findings of this study, researchers could further compare the levels of Saudi learners' FLA with their teachers' teaching methods and level of awareness about FLA. The third limitation of the present study is focusing on FLA at one period of time. Future researchers could investigate changes in FLA levels among EFL learners across different periods to determine when and under which conditions students' anxiety levels fluctuate most.

Moreover, the present study focused on Saudi EFL beginners' FLA levels, causes, and gender variables. For future studies, researchers could conduct similar evaluations of different variables, including age and proficiency level and teachers' methods and awareness of the concept of FLA. Considering the combined effect of these variables on learners' FLA levels will help to diminish FLA among EFL learners.

\section{APPENDix. Modified Foreign LANGUAGE ANXIETy SCALE (FLCAS)}

Dear Students,

This scale is a part of a research study conducted at Bisha University, the Faculty of Arts and Literature. It aims to investigate foreign language anxiety and the performance of English language learners. Please answer these questions based on your feelings and current situation. Your responses are highly valuable for this study. There is no correct or wrong answer. Your responses will be highly confidential and used only for research purposes. Your participation is voluntary in this questionnaire.

I fully understand the aim of this scale and I agree to participate in it:
A. Yes
B. No

Part 1:

Your name in English:

Age:

Male

Gender:

Female

Part 2: Please write a number from 1 to 5 that depicts your feelings about the statement about learning English best, where: $1=$ strongly disagree, $2=$ disagree, $3=$ neutral, $4=$ agree, and $5=$ strongly agree. 


\begin{tabular}{|c|c|}
\hline \multirow{2}{*}{\multicolumn{2}{|c|}{$\begin{array}{l}\text { Item } \\
\text { 1. I am never quite sure of myself when I speak in my English class. }\end{array}$}} \\
\hline & \\
\hline \multicolumn{2}{|l|}{ 2. I worry about making mistakes in English class. } \\
\hline \multicolumn{2}{|l|}{ 3. I tremble when I know that I am going to be called on to speak in English class. } \\
\hline \multicolumn{2}{|l|}{ 4. It frightens me when I do not understand what the teacher is saying in English. } \\
\hline \multicolumn{2}{|l|}{ 5. It bothers me to take more English classes. } \\
\hline \multicolumn{2}{|l|}{ 6. During English class, I find myself thinking about things that have nothing to do with the course. } \\
\hline \multirow{2}{*}{\multicolumn{2}{|c|}{$\begin{array}{l}\text { 7. I keep thinking that the other students are better at languages than I am. } \\
\text { 8. I am usually not at ease during tests in English class. }\end{array}$}} \\
\hline & \\
\hline \multicolumn{2}{|l|}{ 9. I panic when I have to speak without preparing in English class. } \\
\hline \multicolumn{2}{|l|}{ 10. I worry about the consequences of failing in English. } \\
\hline \multicolumn{2}{|l|}{ 11. I understand why some people get so upset over English classes. } \\
\hline \multicolumn{2}{|l|}{ 12. In English class, I can get so nervous that I forget things I know. } \\
\hline \multicolumn{2}{|l|}{ 13. It embarrasses me to volunteer answers in my English class. } \\
\hline \multirow{2}{*}{\multicolumn{2}{|c|}{$\begin{array}{l}\text { 14. I am nervous when I speak English with native speakers. } \\
\text { 15. I get upset when I do not understand what mistake the teac }\end{array}$}} \\
\hline & \\
\hline \multicolumn{2}{|l|}{ 16. Even if I am well prepared for English class, I feel anxious about it. } \\
\hline \multicolumn{2}{|l|}{ 17. I often do not feel like going to my English class. } \\
\hline \multicolumn{2}{|l|}{ 18. I do not feel confident when I speak in English class. } \\
\hline \multicolumn{2}{|l|}{ 19. I am afraid that my English teacher is ready to correct every mistake I make. } \\
\hline \multirow{2}{*}{\multicolumn{2}{|c|}{$\begin{array}{l}\text { 20. I can feel my heart pounding when I am going to be called on in English class. } \\
\text { 21. The more I study for the English test, the more confused I get. }\end{array}$}} \\
\hline & \\
\hline \multicolumn{2}{|l|}{ 22. I feel pressure to prepare very well for English class. } \\
\hline \multicolumn{2}{|l|}{ 23. I always feel that the other students speak English better than I do. } \\
\hline \multicolumn{2}{|l|}{ 24. I feel very self-conscious about speaking English in front of other students. } \\
\hline \multicolumn{2}{|l|}{ 25. When English class moves so quickly, I worry about being left behind. } \\
\hline \multicolumn{2}{|l|}{ 26. I feel more tense and nervous in English class than in other classes. } \\
\hline \multirow{2}{*}{\multicolumn{2}{|c|}{$\begin{array}{l}\text { 27. I get nervous and confused when I speak in English class. } \\
\text { 28. When I am on my way to English class. I feel less confident and less relaxed. }\end{array}$}} \\
\hline & \\
\hline \multicolumn{2}{|l|}{ 29. I get nervous when I do not understand every word the English teacher says. } \\
\hline \multicolumn{2}{|l|}{ 30. I feel overwhelmed by the number of rules I have to learn in order to speak English. } \\
\hline \multicolumn{2}{|l|}{ 31. I am afraid that the other students will laugh at me when I speak English. } \\
\hline \multicolumn{2}{|l|}{ 32. I probably would not feel comfortable around native speakers of English. } \\
\hline 33. I get nervous when the English teacher asks questions that I have not prepared for in advance. & \\
\hline 34. I feel more confident in non-aural and non-oral English classes. & \\
\hline 35. I will not volunteer to answer the teacher's question even if she/he gives me enough time to prepare. & \\
\hline 36. I prefer written over oral skills classes because there is more time for me to prepare my answers. & \\
\hline 37. I avoid speaking even if I know the answer because I am not confident about my pronunciation and accent. & \\
\hline 38. I prefer to answer in writing rather than orally. & \\
\hline 39. I am distracted when the teacher corrects what I am sayin & \\
\hline
\end{tabular}

Your participation is highly appreciated!

\section{REFERENCES}

[1] Abu-Ghararah, A. H. (1999). Learning anxiety and English language achievement of male and female students of university and secondary stages in Al-Madinah Al-Munawwarah: A comparative research study. King Abdulaziz University Journal, 12(1), 3-29. http://dx.doi.org/10.4197/Edu.12-1.2

[2] Alotaibi, G. N. (2014). Teaching English as a foreign language in the early grades of the Saudi public elementary schools: Considering the proposal. Journal of King Saud University, 26, 31-36.

[3] Al-Khotaba, H.H.A., Alkhataba, E. H. A., Abdul-Hamid, S., \& Bashir, I. (2019). Foreign language speaking anxiety: A psycholinguistic barrier affecting speaking achievement of Saudi EFL learners. Arab World English Journal, 10 (4)313- 329. https://dx.doi.org/10.24093/awej/vol10no4.23

[4] Alrabai, F. (2016). Factors underlying low achievement of Saudi EFL learners. International Journal of English Linguistics, 6(3), 21-37. http://dx.doi.org/10.5539/ijel.v6n3p21

[5] Alshahrani, M. A. (2016). The level of anxiety on the achievement of the Saudi EFL learners. Arab World English Journal, 7(3), 65- 76. https://dx.doi.org/10.24093/awej/vol7no3.5

[6] Al-Shammakhi, F., \& Al-Humaidi, S. (2015). Challenges facing EFL teachers in mixed ability classes and strategies used to overcome them. World Journal of English Language, 5(3), 33. https://doi.org/10.5430/wjel.v5n3p33

[7] Al-Saraj, T. M. (2013). Foreign language anxiety in female Arabs learning English: Case studies. Innovation in Language Learning and Teaching, 8(3), 257-278. https://doi.org/10.1080/17501229.2013.837911

[8] Awan, R., Azher, M., Nadeem, M., \& Naz, A. (2010). An investigation of foreign language classroom anxiety and its relationship with students' achievement. Journal of College Teaching and Learning, 7(11), 33-40. https://doi.org/10.19030/tlc.v7i11.249

[9] Bensalem, E. (2017). Foreign language learning anxiety: The case of trilinguals. Arab World English Journal, 8(1), 234-249 https://dx.doi.org/10.2139/ssrn.2945904

[10] Bensalem, E. (2020). Foreign language reading anxiety in the Saudi tertiary EFL context. Reading in a Foreign Language, 32(2), 65-82. 
[11] Bhatti, N., Memon, S., \& Pathan, H. (2016). Investigating the perceptions of Pakistani English language learners on langu age learning anxiety in the EFL classroom. Advances in Language and Literary Studies, 7(5), 23-34 https://doi.org/10.7575/aiac.alls.v.7n.5p.23

[12] Chan, D. Y. C., \& Wu, G. C. (2004). A study of foreign language anxiety of EFL elementary school students in Taipei county. Journal of National Taipei Teachers College, 17(2), 287-320.

[13] Fareh, S. (2010). Challenges of teaching English in the Arab world: Why can't EFL programs deliver as expected? ProcediaSocial and Behavioral Sciences, 2(2), 3600-3604. http://dx.doi.org/10.1016/j.sbspro.2010.03.559

[14] Faruk, S. (2013). English language teaching in Saudi Arabia: A world system perspective. Scientific Bulletin of the Politehnica University of Timişoara Transactions on Modern Languages, 12(2-2), 73-80.

[15] Gawi, E. M. K. (2020). The impact of foreign language classroom anxiety on Saudi male students' performance at Albaha University. Arab World English Journal, 11(2), 258-274. https://dx.doi.org/10.24093/awej/vol11no2.18

[16] Hakim, B. M. (2019). A study of language anxiety among English language learners in Saudi Arabia. Arab World English Journal, 10(1) 64-72. https://dx.doi.org/10.2139/ssrn.3367517

[17] Horwitz, E. K., Horwitz, M. B., \& Cope, J. A. (1986). Foreign language classroom anxiety. The Modern Language Journal, 70(2), 125-132. https://doi.org/10.2307/327317

[18] Khan, I. A. (2011). Challenges of teaching/learning English and Management. Global Journal of Human Social Science, 11(8), 69-80. Retrieved June 24, 2020, from http://socialscienceresearch.org/index.php/GJHSS/article/view/220

[19] Killu, K., Marc, R., \& Crundwell, A. (2016). Students with anxiety in the classroom: Educational accommodations and interventions. Beyond Behavior, 25(2), 30-40. https://doi.org/10.1177/107429561602500205

[20] Koka, N. A., Islam, M. N., \& Osman, M. (2019). Studying foreign language anxiety with its causes and effects: A case of King Khalid University EFL learners. Arab World English Journal, 4-21. https://doi-org.sdl.idm.oclc.org/10.24093/awej/efl1.1

[21] Krashen, S. (1982). Principles and practice in second language acquisition. Oxford: Pergamon Press.

[22] MacIntyre, P. D. (1999). Language anxiety: A review of the research for language teachers. In D. J. Young (Ed.), Affect in foreign language and second language learning (pp. 24-45). McGraw-Hill.

[23] Manipuspika, Y. S. (2018). Correlation between anxiety and willingness to communicate in the Indonesian EFL context. Arab World English Journal, 9(2), 200-217 https://dx.doi.org/10.24093/awej/vol9no2.14

[24] Melchor-Couto, S. (2017). Foreign language anxiety levels in second life oral interaction. ReCALL, 29(1), 99-119. https://doi.org/10.1017/S0958344016000185

[25] Melouah, A. (2013). Foreign language anxiety in EFL speaking classrooms: A case study of first year LMD students of English at Saad Dahlab University of Blida, Algeria. Arab World English Journal, 4(1), 64-76.

[26] Mohammed, A. (2015). EFL effective factors: Anxiety and motivation and their effect on Saudi college student's achievement. Arab World English Journal, 6(2),201-218. https://doi.org/10.2139/ssrn.2834391

[27] Park, H., \& Lee, A. R. (2005). L2 learners' anxiety, self-confidence and oral performance. Paper presented at the Pan-Pacific Association of Applied Linguistics (PAAL), Japan. Retrieved June 23, 2020, from http://www.paaljapan.org/resources/proceedings/PAAL10/pdfs/hyesook.pdf

[28] Pérez C., S. (2018). The role of foreign language anxiety on L2 utterance fluency during a final exam. Language Testing, 36(3) 327-345 https://doi.org/10.1177/0265532218777783

[29] Zemni, B. \& Alrefaee, Y. (2020). Investigating the source of reading anxiety among undergraduate Saudi female EFL students in translation departments. TESOL International Journal, 15(5), 65-77.

[30] Zheng, Y., \& Cheng, L. (2018). How does anxiety influence language performance? From the perspectives of foreign language classroom anxiety and cognitive test anxiety. Language Testing in Asia, 8(13), 1-19. https://doi.org/10.1186/s40468-018-00654

Rahaf A. Alsalooli is an MA postgraduate. She obtained her MA degree in Applied Linguistics from King Khalid University, Saudi Arabia, in 2019. She worked as an instructor at Al-Khaleej institute, Direct English Section, for nearly six months (2015-2016). She also worked as an English lecturer at Bisha University for two semesters (2019-2020). Currently, she is a trainer in medical coding field at Saudi Commission for Health Specialties (SCFHS) in Riyadh, Saudi Arabia.

Mazeegha A. Al Tale' is an associate professor of Applied Linguistics at the Faculty of Languages and Translation-King Khalid University (KKU), Saudi Arabia. She got her Ph.D. degree from King Khalid University. She has taught several English Language face-to-face and online courses for graduate and postgraduate students.

Dr. Al Tale has published articles in Saudi, Arabic, and international journals. She is a certified QM peer reviewer for online courses. She is also a certified external quality reviewer. Her research interests are English as a foreign language (EFL) teaching, digital foreign learning and teaching, and critical discourse analysis. 